CATALLAXY

Volume 3 Issue 1 June 2018

e-ISSN 2544-090X

C www.catallaxy.pl

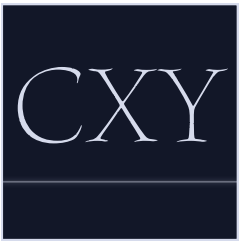

Oryginalny artykut naukowy

otrzymano: 07.05.2018 / zaakceptowano: 25.05.2018 / opublikowano online: 30.06 .2018

Kapera, M. (2018). Analiza determinantów rozmiaru grup społecznych jednostek. Catallaxy, 3(1): 17-25. doi:10.24136/cxy.2018.006.

\title{
Analiza determinantów rozmiaru grup społecznych jednostek
}

\author{
MAREK KAPERA \\ Szkoła Główna Handlowa w Warszawie, al. Niepodległości 162, 02-554 Warszawa, Polska \\ ■kaperamar@gmail.com \\ (iD) orcid.org/0000-0001-7028-5193
}

\section{Abstrakt}

Motywacja: Coraz częściej zwraca się uwagę na to, że stosunki gospodarcze wpływają na sposób kształtowania się relacji społecznych, m.in. poprzez występowanie zjawiska strategicznego dobierania znajomych, aby uzyskać przewagę na rynku pracy, co prowadzi do erozji relacji międzyludzkich.

Cel: Celem artykułu jest weryfikacja empiryczna teorii tłumaczących liczebność znajomych, których posiadają jednostki. Ma to służyć sprawdzeniu czy faktycznie czynniki ekonomiczne można uznać za istotne w kształtowaniu się rozmiarów sieci społecznych oraz czy można obwiniać system gospodarczy za postępującą atomizację społeczeństwa.

Materiały i metody: W artykule użyto metody ekonometryczne dla zmiennych licznikowych, stosowane na mikrodanych. W szczególności zastosowano regresję ujemną dwumianową z logarytmiczną funkcją łączącą.

Wyniki: Wykazano brak istotnego wpływu czynników ekonomiczno-społecznych na kształtowanie się rozmiaru grup społecznych. Wyniki wskazują z kolei na istotny wpływ czynników ewolucyjnych i zwykłej częstotliwości wchodzenia w interakcje z ludźmi.

Stowa kluczowe: sieci spoleczne; mikroekonometria; psychologia ewolucyjna

JEL: C01; D62; C35

\section{Wprowadzenie}

Zdolność kooperacji, współdziałania, pracy w grupie, to od zawsze umiejętności kluczowe do przetrwania. Obecnie, wraz $z$ rozwojem społeczeństw, staje się to bardziej kluczowe zdolność pracy $\mathrm{w}$ grupie wydaje się być niezbędna do rozwoju zawodowego z co najmniej dwóch powodów. Po pierwsze, jest ona wymagana w większości miejsc pracy, więc osoby posiadające ją są bardziej cenione. Po drugie, coraz częściej wyrażana jest opinia, że w rozwoju zawodowym "nie liczy się to, co umiesz, liczy się to, kogo znasz". Ta druga przyczyna spowodowała, że obecnie, już w stosunkowo wczesnym etapie życia, można spotykać się $z$ tym, że zawieranie nowych znajomości i utrzymywanie kontaktów z przyjaciółmi jest podejmowane raczej strategicznie niż spontanicznie. Jest to tzw. „strategiczny networking" prowadzący zazwyczaj do bardzo płytkich, ale szerokich grup znajomych. Warto zwrócić uwagę, że nie każda jednostka w społeczeństwie stosuje strategiczny networking w przedstawionym rozumieniu. Wybór osób, $z$ którymi utrzymuje się kontakty, wpływa nie tylko na życie zawodowe, ale również na jakość życia prywatnego, co powoduje strach wielu osób przed życiem w świecie, gdzie inni po- 
strzegają ich jedynie jako potencjalnie wartościowy kontakt na rynku pracy.

Można się jednak zastanawiać, czy faktycznie takie zachowanie jest racjonalne ekonomicznie. Po uwzględnieniu kosztu niższej jakości życia prywatnego, może się okazać, że nie wcale ekonomizacja społeczeństwa nie musi prowadzić do takiego stanu rzeczy.

Dodatkowo, powstaje pytanie czy faktycznie w zachowaniu ludzkim tak dużo jest wrażliwości na bodźce ekonomiczne. Nawet jeśli homo oeconomicus dążyłby do takiego stanu świata, człowiek jest czymś więcej - jego umysł jest zależny od wielkiego bagażu ewolucyjnego, który być może silniej determinuje zachowania niż finansowe motywacje.

Celem artykułu jest weryfikacja empiryczna teorii tłumaczących liczebność znajomych, których posiadają jednostki. Ma to służyć sprawdzeniu czy faktycznie czynniki ekonomiczne można uznać za istotne w kształtowaniu się rozmiarów sieci społecznych oraz czy można obwiniać system gospodarczy za postępującą atomizację społeczeństwa.

Prezentowane wyniki wskazują, że nie wszystkie teorie spotykane w literaturze wpływają na rozmiary sieci społecznych, przynajmniej na poziomie jednostkowym - a także, że bardzo silnym determinantem jest po prostu to, jak wiele okazji do spotkań $z$ innymi ludźmi ma dana jednostka.

W sekcji 2. opisano występujące w literaturze teorie dotyczące kształtowania się rozmiarów grup społecznych jednostek. Sposób w jaki będą one weryfikowane, ze szczególnym uwzględnieniem opisu stosowanych danych i wybranej w tym celu metody zawarto w sekcji 3. W sekcji 4. zaprezentowano wyniki badania, natomiast w sekcji 5. przedstawiono wnioski z przeprowadzonej analizy.

\section{Przegląd literatury}

W ramach przeglądu literatury wyróżniono trzy prace zajmujące się analizowanym zagadnieniem, reprezentujące przy tym odmienne podejścia i przedstawiające różne wytłumaczenia dla analizowanego zjawiska.
Kluczowym jest badanie S. Oishi i S. Kesebir (2012, ss. 1542-1548), w którym autorzy odpowiadają na pytanie o to, jaki rodzaj zachowania jest optymalny ekonomicznie dla jednostek, w zależności od ich sytuacji socjoekonomicznej. Zwracają oni uwagę na to, że z punktu widzenia jednostki, istnieje konieczność wyboru między szerszą siecią społeczną, która zapewnia większe możliwości (częściej występują przypadki, gdy dana osoba zna kogoś, kto jest w stanie wyświadczyć jej pewną przysługę), ale nie zapewnia jej głębi (żadna $z$ tych osób nie będzie na tyle bliska, aby wesprzeć w naprawdę ciężkiej sytuacji), a siecią wąską, za to głęboką. Z pomocą symulacji komputerowych dochodzą oni do wniosku, że faktycznie nie zawsze racjonalny agent będzie dążył do szerokiej i płytkiej sieci społecznej, ukierunkowanej jedynie na możliwości zawodowe. Będzie się tak działo, jeżeli agent ma stosunkowo dobry status materialny lub jest mobilny geograficznie. Z kolei, w przypadku mało mobilnego geograficznie i słabiej sytuowanego agenta, optymalną strategią okazała się wąska, lecz głęboka sieć społeczna (tradycyjna struktura sieci).

Drugą jest praca $z$ zakresu psychologii ewolucyjnej R. Dunbar (2004). W tym nurcie, rozmiar grupy społecznej jest tłumaczony $z$ użyciem konceptu intencjonalności danej jednostki. Jest ona rozumiana jako zdolność do rozumienia zdań złożonych rodzaju „on myśli, że ja myślę, że ona myśli.... Liczba ogniw takiego zdania, które dana osoba jest w stanie zrozumieć, wyznacza rząd jej intencjonalności. W badaniu argumentowane jest, że intencjonalność jest niezbędna do rozumienia procesów społecznych, ponieważ dzięki niej, ludzie są w stanie orientować się, co dzieje się w życiu ich znajomych. Analogicznie, jest ona potrzebna $w$ zrozumieniu znaczenia zjawisk społecznych oraz sztuki (np. w dziełach W. Szekspira pojawiają się sytuacje społeczne, do zrozumienia których niezbędny jest co najmniej szósty rząd intencjonalności). Za pomocą tego podejścia można wytłumaczyć kształtowanie się znajomości poprzez ewolucyjną zdolność do rozumienia relacji społecznych. 
Kolejną pracą, którą uwzględniono w analizie, jest badanie D. Marmaros i B. Sacerdote (2006, ss. 79-119). Za pomocą badania empirycznego na bazie studentów pierwszego roku pewnego uniwersytetu w USA stwierdzono, że optymalnym predyktorem tego, którzy studenci będą utrzymywali ze sobą kontakty, jest po prostu częstotliwość spotkań. Na tej bazie argumentuje się, że ludzie preferują inwestować swój czas w kontakty $z$ tymi osobami, które kiedyś znowu będą spotykać, ponieważ dzięki temu mają większe szanse na zwrot $z$ tej inwestycji. Sugeruje to, że większe rozmiary sieci społecznych będą miały te osoby, które po prostu obracają się w większej ilości środowisk, ponieważ wtedy będą skłonione do inwestowania swojego czasu w większą ilość osób.

\section{Materiały i metody}

Metoda badania przyjęta $\mathrm{w}$ niniejszym artykule to weryfikacja empiryczna przedstawionych teorii $z$ użyciem ekonometrii. Materiał empiryczny stanowią dane uzyskane $z$ General Social Survey (2018). Wybrano dane $\mathrm{w}$ ujęciu przekrojowym. Zmienne dobrano w sposób pozwalający na odzwierciedlenie teorii empirycznych.

Za S. Oishi i S. Kesebir (2012, ss. $1542-$ 1548), użyto dane o mobilności geograficznej danej osoby oraz o jej dochodzie. Zmienne odpowiadające ze te czynniki to mobility oraz income. Za pomocą pierwszej z nich określono czy dana osoba zmieniła miejsce zamieszkania od czasu ukończenia przez nią 16 roku życia, a więc od końca dzieciństwa. Jest to zmienna czynnikowa przyjmująca trzy wartości: same city (brak zmiany miejsca zamieszkania lub jego zmiana w obrębie tego samego miasta), same state, different city (zmiana miejsca zamieszkania w obrębie tego samego stanu, do innego miasta), different state (przeprowadzka do innego stanu). Według podejścia zaproponowanego przez S. Oishi i S. Kesebir (2012, ss. 1542-1548), osoby zmieniające miejsce zamieszkania powinny posiadać więcej przyjaciół, ponieważ optymalna jest dla nich strategia budowania szerokiej, za to płytkiej sieci społecznej. Poziom odpowiadający za stosunkowo niedaleką przeprowadzkę jest wyróżniony ze względu na to, że zmiana miejsca zamieszkania $\mathrm{w}$ obrębie tego samego stanu, oznacza zazwyczaj bardzo niewielką zmianę, np. przeprowadzkę z miasta na przedmieścia, co nie utrudnia kontaktu $z$ dotychczasowymi znajomymi.

Zmienna income oznacza dochód danej osoby, jest więc zmienną liczbową typu ciągłego. Za jej pomocą oddano sytuację ekonomiczną, w jakiej znajdował się respondent. Osoby znajdujące się w gorszej sytuacji materialnej, powinny posiadać mniej znajomych.

Za D. Marmaros i B. Sacerdote (2006, ss. 79-119), do modelu włączono zmienną memberships, której celem jest oddanie efektu posiadania większej liczby przyjaciół wynikającej z częstszych kontaktów z ludźmi. Jest to zmienna liczbowa oznaczająca liczbę organizacji, do których należy respondent. Ponieważ rząd intencjonalności danej osoby nie jest zmienną obserwowalną, użyto zmienne, które powinny wykazywać bardzo silną zależność od niego (lub on zależność od nich). Są to zmienne membersArt, popular, considerate oraz sex. Wszystkie $z$ tych zmiennych są zmiennymi czynnikowymi.

Pierwsza $z$ nich, dostarcza odpowiedzi na pytanie czy dana osoba należy do jakiejkolwiek grupy artystycznej lub literackiej (wartości: yes - należy, no - nie należy). Zmienną tę wybrano, ponieważ, jak zwraca uwagę $\mathrm{R}$. Dunbar (2004), do zrozumienia sztuki niezbędny jest wysoki rząd intencjonalności (dla osoby o niskiej intencjonalności, niemożliwe byłoby zrozumienie zawiłych powiązań między bohaterami powieści).

Dwie kolejne zmienne: popular i considerate, mają podobną konstrukcję - respondenta poproszono o podanie cech uznanych za ważne, które chciałyby posiadać oraz cech według niego zbędnych.

W przypadku zmiennej popular respondent uznal, że istotnym dla niego jest bycie popularnym/lubianym. Zmienna ta przyjmuje następujące wartości: important (cecha uznana za ważną), least important (cecha uznana za pozytywną, ale nie jest tak bar- 
dzo istotna, jak inne), not mentioned (cecha niewymieniona).

W przypadku zmiennej considerate respondent uznał za istotne cechy szeroko rozumiane jako „bycie osobą rozumiejącą innych". Zmienna przyjmuje następujące wartości: desirable (cecha uznana za ważną, którą respondent chciałby posiadać), non-desirable (cecha, której respondent nie chciałby posiadać lub niewymieniona).

Zmienne popular i considerate przyjęto, ponieważ $w$ obydwu przypadkach uznanie ich jako istotnych, oznacza silne ukierunkowanie respondenta na życie społeczne, co także wskazuje na wysoką intencjonalność osoby o niskiej intencjonalności nie uzyskują satysfakcji z życia społecznego. Przykładowo, według R. Dunbar (2004), u mężczyzn intencjonalność rozwija się później i wolniej niż u kobiet, co tłumaczy dlaczego chłopcy w okresie dojrzewania są aspołeczni i ich kontakty z rówieśnikami „ograniczają się do kopania piłki", podczas gdy dziewczynki w okresie dojrzewania bardzo silnie przeżywają aspekty społeczne (wyższy poziom intencjonalności u nich pozwala im czerpać o wiele większą satysfakcje $z$ uczestnictwa w życiu społecznym).

Uzasadnia to także włączenie do modelu zmiennej sex - intencjonalność u mężczyzn rozwija się wolniej, przez co mają średnio niższy jej poziom.

Jako zmienną objaśnianą przyjęto friends, czyli deklarowaną przez daną osobę liczbę najbliższych przyjaciół (zmienna liczbowa). Pewien problem sprawia fakt, że każdy respondent mógł inaczej rozumieć pojęcie „bliski przyjaciel”, co może powodować nieporównywalność odpowiedzi oraz występowanie obserwacji odstających. Dla pewności, że porównywane są tylko osoby o podobnym rozumieniu pytania $\mathrm{w}$ ankiecie (czyli podobnie rozumiejące pojęcie bliskiego przyjaciela) , usunięto obserwacje uznane za odstające (o wartości większe niż dwadzieścia pięć). Poziom ten uznano za bezpieczny, ponieważ V. Arnaboldi i in. (2015), wskazują, że u większości osób można wyróżnić dobrze widoczne cztery kręgi znajomych o liczebności około pięć, piętnaście, pięćdziesiąt oraz 150. Roz- patrywany był krąg najbliższych przyjaciół, a więc o oczekiwanej liczebności około pięciu osób, podczas gdy dwadzieścia pięć to liczba znajomych zazwyczaj należąca do drugiego lub nawet trzeciego (w sensie bliskości) kręgu. Wydaje się to więc bezpiecznym progiem.

W pierwszej kolejności rozważono model regresji Poissona $z$ logarytmiczną funkcją łączącą (model (1)). $Z$ powodu występowania zjawiska nadmiernego rozproszenia $\mathrm{w}$ danych, zastosowano regresję ujemną dwumianową.

\section{Wyniki badania}

Wyniki estymacji modelu (1) dla regresji Poissona przedstawiono $\mathrm{w}$ tabeli 1 . $Z$ powodu występowania w nim nadmiernego rozproszenia, estymowano model ujemny dwumianowy (model (2)). Wyniki estymacji przedstawiono są w tabeli 2 .

Nie wszystkie, uzyskane wyniki estymacji były zgodne $z$ tym, co zakładała teoria. Po pierwsze, obydwie zmienne (mobility i income), których wpływ zakłada S. Oishi is. Kesebir (2012, ss. 1542-1548), okazały się nieistotne statystycznie. Wydaje się więc, że przynajmniej w skali jednostkowej, podejście tych autorów nie opisuje dobrze zachowań ludzi. Nie wyklucza to jednak, że ta koncepcja bardzo dobrze działa na danych wygładzonych poprzez agregacje, np. rejonami. Można także zauważyć, że oszacowania parametrów przy tych zmiennych miały przeciwny znak niż zakładany przez teorie. Jednak, przy tak dużym błędzie standardowym, wydaje się nie mieć to znaczenia (można uznać znak za przypadkowy). Przeciwny do oczekiwanego znak otrzymano również $\mathrm{w}$ przypadku zmiennych sex oraz membersArt, przy czym druga $z$ tych zmiennych okazała się silnie nieistotna statystycznie. Sprawia to, że znak oszacowania parametru nie ma znaczenia, co nie zmienia faktu, że był on nieoczekiwany. Bardzo prawdopodobne, że wynika to $z$ silnej korelacji zmiennych memberships oraz membersArt. Szacując model (3) bez zmiennej memberships (oraz bez zmiennych zakładanych przez S. Oishi i S. Kesebir (2012, ss. 1542-1548), otrzymano oszacowania przedstawione $\mathrm{w}$ ta- 
beli 3., gdzie zmienna membersArt miała oczekiwany znak i była istotna statystycznie.

Ciężko jednak ocenić, czy istotność zmiennej membersArt w ostatnim, oszacowanym modelu (3) można intepretować w kontekście istotnego wpływu intencjonalności na model. Istotność tej zmiennej można tłumaczyć też poprzez koncepcje D. Marmaros i B. Sacerdote (2006, ss. 79-119). Na tę drugą interpretację wskazywałby fakt nieistotności tej zmiennej w modelu (2), w którym obecna jest zmienna memberships. Wpływ faktu, że organizacja, do której się należy ma profil artystyczny, nie wydaje się być istotny. W związku $z$ tym, zmienna memberships wydaje się być lepszym wyborem niż zmienna membersArt. $Z$ tego powodu oszacowano ostatecznie model (4) ze zmienną memberships, bez zmiennej membersArt. Oszacowania parametrów przedstawiono w tabeli 4. Należy zwrócić uwagę, że logarytm wiarygodności modelu (4) był większy niż dla modelu (3), w związku z czym uznano model (4) za preferowany.

Znaki przy oszacowaniach parametrów modelu (4) ( $z$ wyjątkiem tego przy zmiennej sex), były zgodne z oczekiwanymi. Wszystkie zmienne, $z$ wyjątkiem zmiennej considerate, były też istotne statystycznie (mimo nieistotności tej zmiennej, nie będzie ona usunięta $z$ modelu). Efekty krańcowe dla średniej przedstawiono $\mathrm{w}$ tabeli 5.

Wartość oczekiwana (krańcowy przyrost stałej) liczby bliskich przyjaciół wyniosła około pięciu, co zgadza się z podejściem V. Arnaboldi $i$ in. (2015). Pozwala to stwierdzić, że jeżeli nawet faktycznie niektóre osoby wymienily liczbę znajomych należących do szerszej grupy niż ta najbliższa, nie była to istotna liczba osób. Wartości pozostałych, krańcowych przyrostów są interpretowalne w zwyczajowy sposób. W przypadku zmiennych czynnikowych: ile razy zwiększy się oczekiwana liczba znajomych (ceteris paribus), jeżeli zmienna czynnikowa zmieni się z kategorii bazowej na daną kategorię (w przypadku zmiennej popular, kategorią bazową jest important, natomiast dla zmiennej considerate, jest to non-desirable, dla zmiennej sex, jest to bycie kobietą (female).
W przypadku zmiennej memberships, oznacza to, ile razy więcej znajomych miała średnio osoba należąca do jednej organizacji więcej, w porównaniu do osoby należącej do średniej liczby organizacji. W niniejszej analizie jest to 1,075 razy więcej.

\section{Zakończenie}

W niniejszym artykule skonstruowano model opisujący kształtowanie się liczby bliskich przyjaciół dla danej osoby. Czynniki, za pomocą których modelowana była liczba przyjaciół, zaczerpnięto $z$ prac teoretycznych. Wyniki estymacji zdają się zaprzeczać tezie, że osoby dobierają liczbę znajomych, aby zachowywać się optymalnie pod warunkiem jednostkowych dla nich czynników socjoekonomicznych. Wydają się za to wspierać koncepcję D. Marmaros i B. Sacerdote (2006, ss. 79-119), o przypadkowym kształtowaniu się znajomości. Można więc uznać, że prawdziwe w tym przypadku jest powiedzenie „szukajcie a znajdziecie". Wyniki są z kolei nierozstrzygające w odniesieniu do koncepcji psychologii ewolucyjnej, przypisujących kształtowanie się liczby znajomych intencjonalności danej osoby. Co prawda, większość zmiennych użytych $\mathrm{w}$ modelu, które miały reprezentować intencjonalność okazała się istotna statystycznie oraz posiadała oszacowania parametrów o znaku zgodnym z przewidywanym. Niepokojący był jednak dodatni znak przy zmiennej sex_male. Wyższy poziom intencjonalności mają zazwyczaj kobiety. Można to tłumaczyć tym, że kobiety są zazwyczaj mniej skłonne do tworzenia dookoła siebie „propagandy sukcesu."Jednak nie można, na bazie otrzymanych wyników, jednoznacznie stwierdzić, że wspierają one tezy psychologii ewolucyjnej.

\section{Bibliografia}

Arnaboldi, V., Passarella, A., Conti, M., \& Dunbar, R. (2015). Online social networks: human cognitive constraints in Facebook and Twitter personal graphs. Amsterdam: Elsevier.

Dunbar, R. (2004). The human story: a new history of mankind's evolution. London: Faber and Faber. 
General Social Survey. (2018). Pobrane 29.05.2018 z http://gss.norc.org.

Marmaros, D. i Sacerdote, B. (2006), How do friendships form? The Quarterly Journal of Economics, 121(1).

Oishi, S., i Kesebir, S. (2012). Optimal social-networking strategy is a function of socioeconomic conditions. Psychological Science, 23(12). doi:10.1177/0956797612446708.
Informacje uzupetniające

Wkład autorski: autor zaakceptował ostateczną wersję artykułu.

Źródła finansowania: artykuł został w całości sfinansowany ze środków własnych autora.

Uwagi: wyniki badania byly zaprezentowane na VIIl Ogólnopolskiej Konferencji Naukowej z cyklu Problemy gospodarki światowej (Toruń, 20.04.2018). 
Aneks

Tabela 1.

Wyniki oszacowań regresji Poissona (model (1))

\begin{tabular}{lcccc}
\hline \multicolumn{1}{c}{ Zmienna } & Ocena parametru & Błąd standardowy & Wartość z & Wartość p \\
\hline stała & 1,6500 & 0,0365 & 45,2030 & $0,0000^{* * *}$ \\
income & 0,0000 & 0,0000 & $-0,5760$ & 0,5649 \\
memberships & 0,0686 & 0,0064 & 10,7560 & $0,0000^{* * *}$ \\
membersArt_yes & $-0,0170$ & 0,0411 & $-0,4140$ & 0,6792 \\
popular_least_important & $-0,1421$ & 0,0343 & $-4,1480$ & $0,0000^{* * *}$ \\
popular_not_mentioned & $-0,1691$ & 0,0350 & $-4,8270$ & $0,0000^{* * *}$ \\
considerate_desirable & 0,0927 & 0,0331 & 2,8000 & $0,0051^{* * *}$ \\
mobility_same_city & 0,0309 & 0,0263 & 1,1740 & 0,2406 \\
mobility_same_state_different_city & 0,0220 & 0,0300 & 0,7350 & 0,4625 \\
sex_male & 0,1510 & 0,0246 & 6,1400 & $0,0000^{* * *}$ \\
\hline odchylenie zerowe modelu: 5063 przy 1385 stopniach swobody & & \\
odchylenie resztowe modelu: 4856 przy 1376 stopniach swobody & & \\
kryterium AIC:9350 & & & \\
\hline
\end{tabular}

Żródło: Opracowanie własne.

Tabela 2.

Wyniki oszacowań regresji ujemnej dwumianowej (model (2))

\begin{tabular}{lcccc}
\hline \multicolumn{1}{c}{ Zmienna } & Ocena parametru & Błąd standardowy & Wartość z & Wartość p \\
\hline stała & 1,6460 & 0,0695 & 23,6650 & $0,0000^{* * *}$ \\
income & 0,0000 & 0,0000 & $-0,3250$ & 0,7450 \\
memberships & 0,0736 & 0,0013 & 5,8660 & $0,0000^{* * *}$ \\
membersArt_yes & $-0,0965$ & 0,0804 & $-0,4140$ & 0,9044 \\
popular_least_important & $-0,1446$ & 0,0660 & $-4,1480$ & $0,0283^{* *}$ \\
popular_not_mentioned & $-0,1608$ & 0,0670 & $-4,8270$ & $0,0164^{* *}$ \\
considerate_desirable & 0,0866 & 0,0623 & 2,8000 & 0,1643 \\
mobility_same_city & 0,0165 & 0,0493 & 1,1740 & 0,7382 \\
mobility_same_state_different_city & 0,0104 & 0,0563 & 0,7350 & 0,8532 \\
sex_male & 0,1535 & 0,0465 & $0,0010^{* * *}$ \\
\hline odchylenie zerowe modelu: 1527 przy 1385 stopniach swobody & & \\
odchylenie resztowe modelu: 1502 przy 1376 stopniach swobody & & \\
kryterium AIC: 7588 & & & \\
\hline
\end{tabular}

Żródło: Opracowanie własne. 
Tabela 3.

Wyniki oszacowań regresji ujemnej dwumianowej (model (3))

\begin{tabular}{lcccc}
\hline \multicolumn{1}{c}{ Zmienna } & Ocena parametru & Błąd standardowy & Wartość z & Wartość p \\
\hline stała & 1,7545 & 0,0600 & 29,2510 & $0,0000^{* * *}$ \\
membersArt_yes & 0,1858 & 0,0728 & 2,5520 & $0,0107^{* *}$ \\
popular_least_important & $-0,1097$ & 0,0664 & $-1,6510$ & $0,0987^{*}$ \\
popular_not_mentioned & $-0,1498$ & 0,0677 & $-2,2120$ & $0,0270^{* *}$ \\
considerate_desirable & 0,0965 & 0,0628 & 1,5360 & 0,1246 \\
sex_male & 0,1611 & 0,0432 & 3,7250 & $0,0002^{* * *}$ \\
\hline
\end{tabular}

odchylenie zerowe modelu: 1530 przy 1385 stopniach swobody

odchylenie resztowe modelu: 1504 przy 1376 stopniach swobody

kryterium AIC: 7613

Źródło: Opracowanie własne.

Tabela 4.

Wyniki oszacowań regresji ujemnej dwumianowej (model (4))

\begin{tabular}{lcccc}
\hline \multicolumn{1}{c}{ Zmienna } & Ocena parametru & Błąd standardowy & Wartość z & Wartośćp \\
\hline stała & 1,6542 & 0,0614 & 26,9310 & $0,0000^{* * *}$ \\
memberships & 0,0724 & 0,0111 & 6,5080 & $0,0000^{* * *}$ \\
popular_least_important & $-0,1458$ & 0,0659 & $-2,2140$ & $0,0269^{* *}$ \\
popular_not_mentioned & $-0,1610$ & 0,0669 & $-2,4060$ & $0,0161^{* *}$ \\
considerate_desirable & 0,0862 & 0,0622 & 1,3870 & 0,1655 \\
sex_male & 0,1485 & 0,0428 & 3,4740 & $0,0005^{* * *}$ \\
\hline odchylenie zerowe modelu: 1562 przy 1385 stopniach swobody & & \\
odchylenie resztowe modelu: 1502 przy 1376 stopniach swobody & & \\
kryterium AIC: 7580 & & & \\
\hline
\end{tabular}

Źródło: Opracowanie własne.

Tabela 5.

Efekty krańcowe

\begin{tabular}{lc}
\hline \multicolumn{1}{c}{ Zmienna } & Ocena parametru \\
\hline stała & 5,229 \\
memberships & 1,075 \\
popular_least_important & 0,864 \\
popular_not_mentioned & 0,851 \\
considerate_desirable & 1,090 \\
sex_male & 1,160 \\
\hline
\end{tabular}

Źródło: Opracowanie własne. 
Analysis of determinants of the size of social groups of individuals

\section{Abstract}

Motivation: Increasingly noted phenomenon is the impact of economics on social relations, for example due to existence of strategic networking between individuals, to gain advantage at labour market. It is believed to lead to erosion of interpersonal relations.

Aim: The aim of the article was empirical verification of main theories concerning the size of social networks of individuals. It is to the point of verification whether economic factors influence construction of the social networks of individuals, and whether we are justified in blaming the economic system for progressing atomization of society. Materials and methods: For verification of theories, the econometric methods for count data, used on microdata were applied. More specifically, a negative binomial regression with a logarithmic link function was used.

Results: There was no significant impact of socioeconomic factors on size of social groups. The results imply instead significant impact of evolutionary and chance factors.

Keywords: social networks; microeconometry; evolutionary psychology JEL: C01; D62; C35 
